\title{
Leveraging Educational Functions of Inspirational Video: Emerging Students' Sense of Community Development
}

\author{
${ }^{* 1}$ Adi Suryani, ${ }^{2}$ Soedarso, ${ }^{3}$ Zainul Muhibbin, ${ }^{4}$ Marsudi and ${ }^{5}$ Ni Wayan Suarmini \\ ${ }^{* 1}$ Institut Teknologi Sepuluh Nopember, Indonesia, adisuryani.rahman@gmail.com \\ ${ }^{2}$ Institut Teknologi Sepuluh Nopember, Indonesia, soedarsoits@gmail.com \\ ${ }^{3}$ Institut Teknologi Sepuluh Nopember, Indonesia, muhibbin@mku.its.ac.id \\ ${ }^{4}$ Institut Teknologi Sepuluh Nopember, Indonesia, marsudi@ gmail.com \\ ${ }^{5}$ Institut Teknologi Sepuluh Nopember, Indonesia, suarmini@ mku.its.ac.id
}

\section{Submitted: 30/08/2020 Revised: 31/10/2020 Accepted: 25/11/2020}

How to cite this article: Suryani, Soedarso, Muhibbin, Marsudi \& Suarmini. (2020). Leveraging educational functions of inspirational video: Emerging students' sense of community development. International Journal of Education, Language and Religion, 2(2), pp. 85-101. http://doi.org/10.35308/ijelr.v2i2.2530

\begin{abstract}
Today, the use of video is prevalent in facilitating learning process. Commonly, it is used to deliver cognitive content. By using video, knowledge the delivered content can be easier to understand, clearer to grasp and becomes more interesting. Many studies devoted to explore the cognitive functions of video. However, how video can affectively contribute to self-development and potential community developed remains unexplored widely. This study intends to examine inspirational video impacts on students' analysis, inspiration and motivation to develop themselves and contribute their self-development to wider community. The study adopts a qualitative method. The data are collected from thirty-eight student participants. The study finds that video can stimulate the student-participants to develop self-commitment to undertake self-learning, perseverance, hard work, diligence, emotion regulation and elf-efficacy. The study also reveals that the student participants develop commitment to contribute their learning to community development. Thus, it can be indicated that video is a potential development tool, which can promote human capital improvement through self-learning and self improvement and social capital, through social cohesion and engagement for succeeding community development.
\end{abstract}

\section{Keywords}

inspirational video, self-development, community development, affective function

\section{Introduction}

The use of video to support learning is becoming prevalent in education sector. This application updates learning pedagogy and learning tool from the past traditional ones into technological-enhanced learning approaches. It is widely acknowledged that video can be utilized for gaining and disseminating knowledge and information. However, students' cognitive development is not the only benefit gained from the use of video. Affective gains can also be achieved from incorporating video into other active learning activities. The visual and auditory features of video can attract students' attention, entertain and understand the presented knowledge in more joyful and memorable ways.

Today technology-enriched environment enables teachers to explore which video fits the students' needs and how the video can be integrated into other learning activities to achieve specific learning goals. This is because different video has distinctive main focus and major purpose, such as field trip 
video, motivating, demonstration, multimedia presentation, historical footage, time and space manipulation videos (Woolfitt, 2015, p. 12). The internet allows the online learning and online videobased learning can be executed. Several online media and application flourish and promote various use of video. YouTube, for instance, enables teachers and students to download video freely. WhatsApp application enables video sharing across the world and vlog media support the creation and dissemination of video. This technological-surrounded environment becomes trend and reflects the learning needs and styles of the millennial. Today's education paradigm is changing as it is not restricted by time and space anymore and increasing variety of learning modes (Douad, n.d.).

Video is not only providing cognitive benefits, but also affective advantages. Video can stir emotion of the watchers/students. Many today viral videos, taken to capture real circumstance in society, can easily and widely attract attention and influence emotion of global viewers. Sad video can rise sympathy and help from viewers, fun video makes them laugh or creative video may inspire its' viewers. Thus, video has tremendous roles in enabling its viewers to experience certain emotion.

This study aims to examine the function of inspirational video in stimulating students' awareness, character and behavior to contribute to community development in their areas. Currently, many motivating videos can be downloaded and displayed to present motivating materials to inspire students. They are devised in various formats: inspirational speech, inspirational quotes, life stories. Many videos on how to burn an individual motivation to success in their life have been widely acknowledged. However, how video can be utilized to motivate students to contribute to their community issues problem solving and contribution remains unaddressed. Thus, this study intends to fill the knowledge and practice gap on how video can be potentially used to grow young people's (students in higher education) development awareness, character and pro- development behavior through an inspirational figure.

\section{Educational Benefits of Video}

Video is becoming popular learning tool today. Many school teachers and higher education educators find video as vital roles in supporting their material delivery. Using digital resources is prevalent in present education (Buzzetto-More, 2014; Chao et al., 2016). To support their teaching, many teachers start using online open source (Bzonková, 2018; Kokić \& Rukavina, 2017), for instance YouTube. YouTube has considerable roles in facilitating learning instruction and allowing teachers to optimize video sharing facilities (Buzzetto-More, 2014). Moreover, video allows the use of multimodal pedagogy by incorporating it into other activities (Pirhonen \& Rasi, 2017). From the learners aspects, YouTube facilitates learners engagement (Brame, n.d.; Buzzetto-More, 2014), learners' understanding and satisfaction (Buzzetto-More, 2014). Videos supplement classroom teaching (Brecht, 2012) and instructional tools (Noraddin, 2015). Video provides authentic materials (Bzonková, 2018).

Many studies on video-based pedagogy address implementation and flexibility of video for supporting any types of learning. Video is used across different subjects, including education for foreign subject, for instance English subject (Bzonková, 2018), complex practical subjects, such as engineering (Stefanova, 2014; Usón et al., 2018), perceived hard subject, such as mathematics (Chao et al., 2016) and natural living science, such as biology (Kuchel et al., 2014), utilize video to clarify their contents. Many studies identify tremendous benefits of video for promoting learning. Video adds learning modality. It enriches teaching-learning methods in higher education and allows the prevalence of blended-learning (Brame, n.d.). Video drives learning changes in higher education from traditional lecture system into hybrid, collaborative and online teaching (Woolfitt, 2015). Video is used in any occasion of teaching: classroom, lab, exam, homework (Brecht, 2012). Video can be incorporated into other teaching activities (Bzonková, 2018).

Video enhances cognitive and affective learning. Brame (n.d.) reveals that effective facilitated learning video contains three learning elements: cognitive contents, content-stimulating engagement and active learning. Video promotes knowledge acquisition and inspiration (Miller et al., 2011), 
clarifies concept (Choe, 2017) and cognitive content (Ljubojevic et al., 2014), enhances creativity (Choe, 2017), enables the learners to review and re-visit learning materials (Woolfitt, 2015) and stimulates critical thinking (Carmichael et al., n.d.). Video can be used to facilitate training by clarifying information-knowledge conversion through demonstration and presentation (Stefanova, 2014). Documentary video enables learners to develop local issues analyzing skills (Kuchel et al., 2014), literacy skills and building argument (Kuchel et al., 2014). Other type of video, cases video stimulates online discussion forum (Kokić \& Rukavina, 2017). Affectively, video is considered as motivating learning tool (Bzonková, 2018; Noraddin, 2015). It increases students' motivation to learn by making learning materials and activities more attractive (Usón et al., 2018) and transforming hard material into joyful one (Chao et al., 2016). Moreover, entertainment can be inserted into video (Ljubojevic et al., 2014). Video is the source of motivation and train lessons (Chao et al., 2016). Video affects students' motivation, satisfaction and successful results (Ljubojevic et al., 2014). Learning motivation and satisfaction can transform ordinary students into highly-motivated learners who are energetic, passionate, engaged, focused, hard work, hard try, consistent, joyful and interested in (Garris \& Driskell, 2002, cited in Noraddin, 2015, p. 444). Students' intrinsic learning motivation can be grown by providing various interesting, meaningful tasks and engaged activities (Hoskins \& Newstead, 2003, p. 35).

Many researches address the dual functions of video in facilitating individual and group learning. Video facilitates individual learning at any pace (Brecht, 2012) and learning independently (Yuen et al., 2018). Group learning can be enhanced by video employment. Video increases engagement and motivation in group-project based learning (Lund, 2016), learners' participation, interactivity among learners and conciseness (Choe, 2017). Thus, it is a collaborative tool (Noraddin, 2015).

Educational video contributes to the foundation of learning characters which is needed for students' learning sustainability and investment for long-term or future learning. Video increases students' selfefficacy in learning hard materials, such as mathematic and sciences, participation in technology enhanced-learning and PBL (Liu, et.al., 2016, cited in Chao et al., 2016, p. 257). Video enables selfdirected learning (Yuen et al., 2018), evokes curiosity, stirs emotion, presents authenticity and introduces aesthetics (Choe, 2017). Furthermore, video forms learning character strengths as it empowers learners' communicative competence (Bzonková, 2018), learners' self confidence (Liu, et. al. 2006, cited in Yuen et al., 2018, p. 257), openness to wider learning experiences (Ljubojevic et al., 2014). A case study video elaborated in group learning encourages the students to learn communication, value relationship, creativity, collaboration, critical thinking and implements studentcentred approach (Pintrich, 2000).

\section{Affective Dimension of Video}

This study is focused on examining affective roles of video. Therefore, we intend to explore several concepts of video's affective function in more detail.

Many studies indicate the motivating function of video. Video is an affective tool (Ma'rifah \& Wulandari, 2013). The use of video increases students' motivation (Bravo et al., 2011; Panagiotidis et al., 2018; Willmot et al., 2012) by presenting humour, varying activities, supplying age-appropriate narration, clarifying using examples and open-ended questions (Ma'rifah \& Wulandari, 2013), incorporating text-video-image-sound (Handley, 2008). Video provides multimodal pedagogy (Pirhonen \& Rasi, 2017). This multimodal characteristic enables teachers to combine and be creative in collaborating pedagogy. Video increases the variety of learning activities, avoid monotonous activities (Tjakrawadhana, n.d.). Multimodal video increases students' motivation and positive emotion experience, such as sensible, challenging, entertaining, interesting, nice, meaningful (Pirhonen \& Rasi, 2017). Thus, wider learning experiences can be felt by learners (Pirhonen \& Rasi, 2017; Willmot et al., 2012). Video allows the learners to engage emotionally through enjoyment, engagement and motivation (Carmichael et al., n.d.). Thus, what makes video more attractive than classical material handout is the evocation of learners' positive emotion. Video allows more positive 
emotion towards the materials learnt and group participation, for instance through group competition (Park \& Jung, 2016).

Learning motivation and satisfaction resulted from video use implicate on students' learning success. Motivation is a key in education success (Williams \& Williams, n.d.) since motivated students are enthusiastic and engaging actively in learning process (artikel video as new teaching tool). There are three major aspects in ensuring students motivation: students (sources of their motivation, socialpersonal factors, learning needs, learners' well-being, energy and focus efficiency, meaningful connection with the work, conscientiousness and achievement, learning habits and time, lecture attendance, long term educational plan), teacher contribution (teachers' knowledge and motivation, teachers skills and qualification, motivating students through test, human relation skills, being details, understanding how to approach students, students' strength, relationship building and enthusiasm), content aspects (promotes students' success, ownership, provides choices, critical thinking, competency, connection feeling, novelty, real life relevance, variety, use of technology and technological rich environment), learning process aspects (incentives, self-learning, flexibility, objective, verbal conformity, framing variety, objective criteria, appreciation, guided forum, casework, reinforcement, constructive interaction, storytelling, collaboration), and environment aspects (environment effectiveness, learning system, self information, learning empowerment, engagement, teamwork, structure, online learning and literate environment) (Williams \& Williams, n.d.). Similarly, Malouff et. al (2008) suggest several ways to motivate learners which is executed by fitting content to values and goals, helping students reach their learning objectives, designing influential learning models, developing health teacher-student relationship, appreciating the students, motivating students, increasing students' self-confidence, devising engaged teaching methods, implementing teaching cycle, providing encouraging feedback, supervising learners' motivation and fitting teaching methods to students motivation (Malouff et al., 2008). High motivation is indicated by the increasing confidence, attention, relevance and positive attitudes towards learning (based on ARC model by Keller (1987, cited in Douad, n.d., p. 18) and is confirmed by Chung \& Lee (2018). Multimedia stimulates students' learning sensory and provides authentic materials to motivate learners (Gilakjani, 2012). Learners' motivation is determinant successful learning and real-life success since highly motivated learners may have strong enthusiasm in any life circumstances (Daskalovska et al., 2012; Murphy \& Rodríguez-Manzanares, n.d.; Rakhmanina \& Kusumaningrum, 2017; Shaheen et al., 2013). Moreover, motivation promotes self-regulated learning (Pintrich, 1999).

It is documented by many studies that video enables learners to develop soft skills. Video increases students' learning autonomy (Willmot et al., 2012), creativity and self-efficacy (Francis, 2017; Liu et al., 2012), self-regulated capacity (Pintrich, 1999). Video enhances team communicative skills (Willmot et al., 2012). Video blogging can increase students' affection and social skills, including communicative skills, learning consciousness, motivation, disciplinary and social interaction (Rakhmanina \& Kusumaningrum, 2017).

The motivation studies show that technology facilitates students' learning, not only for present time, but also for students' future investment. Technology is not only enabling students to learn the content, but also for servicing wider and long term purposes, preparing the students to engage in more global context, be responsible citizen and 21 st century active learners (Wieking, 2016). Technology allows learners to engage and invest for their long-term learning (Wieking, 2016).

\section{Inspirational Learning and Role Models' Roles}

One of many motivating approaches is the inspiring method. Many studies addresses the role of inspirational figures in elevating learners' motivation by acknowledging various inspirational figures, such as exemplary practitioners, inspiring teachers and other professionals (Blaylock et al., n.d.; Derounian, 2017; Jensen et al., 2014; Sammons et al., 2016). Inspirational behavior demonstrated by an exemplary teacher, for instance, can induce sustained learning motivation (Jensen et al., 2014) and life-long learning (Manning et al., 2011). This is consistent with Rudhumbu (2014) who suggests some 
ways to motivate students: increasing confidence, providing aspirations, feedback, appreciating learners' tasks. The evocation of affective aspect and cognitive domain sustain students learning. Learning sustainability needs the integration of knowledge, skills and affection (Shephard, 2008).

Inspiration can come from role models. Role model approach is usually used to motivate an individual (role aspirant) to reach certain goals (Morgenroth et al., 2015). General practitioners, family members and senior students can be exemplary inspirational figures (Chlosta et al., 2012; Joubert et al., 2006). Many studies highlight the substantive role of role models. Role model is an influential actor guiding an individual's life decision and career development (Bosma et al., 2011; Muofhe \& du Toit, 2011). Excellent role models provide competence, proficiency and humanistic personal attributes (Badam \& Pavani, 2018; Haque, 2017; Weissmann et al., 2016). This is confirmed by Piccinato et al. (2014) by asserting that role models provide exemplary humanistic characters besides technical samples. Role models influence role aspirant's behavior (Hurd et al., 2011), belief and qualities (Berger et al., 2009), identity process (Hurd et al., 2011) and role aspirant's career development (Valero et al., 2017). Role models contribute to role aspirant's autonomy sense development, competence and feeing of relatedness (Stern et al., 2017), encourage role aspirants, reinforce their intention and enable the adoption of new intention (Morgenroth et al., 2015). Role models provide skills and expertise imitated by role aspirants (Badam \& Pavani, 2018). The above studies indicate that role models possess inspirational qualities which can affect role aspirants' motivation. Inspiration relates to motivation as inspiration generates motivation, while motivation sustains inspiration (Pintrich, 1999). Role models can ignite students' motivation and imagination (Popenici, n.d.). Besides learning materials, students need role model for providing soft skills in practice (Joubert et al., 2006). In spite of the powerful influence of role models, their inspirational qualities can influence the role aspirants only if the demonstrated qualities are congruent with the role aspirants' regulatory focus (Lockwood et al., 2002).

\section{Method}

This study aims to examine the students' analysis on a presented inspirational figure based on case study video. It is expected that from viewing the video and actively engage in group discussion and analysis, the student-participants can extract inspirational lessons, especially lessons on what moral personal/individual, humanistic and social values.

The study adopts a qualitative method. A case study is selected as the research design since it is congruent with the objective of the study. Case study involves the structured information gathering about particular people, social circumstance, events or group of people allowing the researchers understand the aspects related to the investigated people, group, or social context (Berg, 2004, cited in Ruttherford, 2012, p. 119). Case study is commonly used in qualitative research, even though it is not restrictedly bound to it (Ruttherford, 2012, p. 119). The research participants are thirty-eight students who enroll English language topic in 2020. The activity is part of classroom activity which occurs in a natural setting and classroom learning process. Qualitative researchers incline to gather data at natural site (Creswell, 2007, p. 37). The data are collected through group written analysis on the presented case study video. The gathered data is analyzed by implementing thematic analysis by reading, crossing and grouping the collected data into emerging themes. The themed data are interpreted and linked to existing studies.

The presented video is downloaded from online open source, YouTube. Below are several screenshots and general illustration of the video.
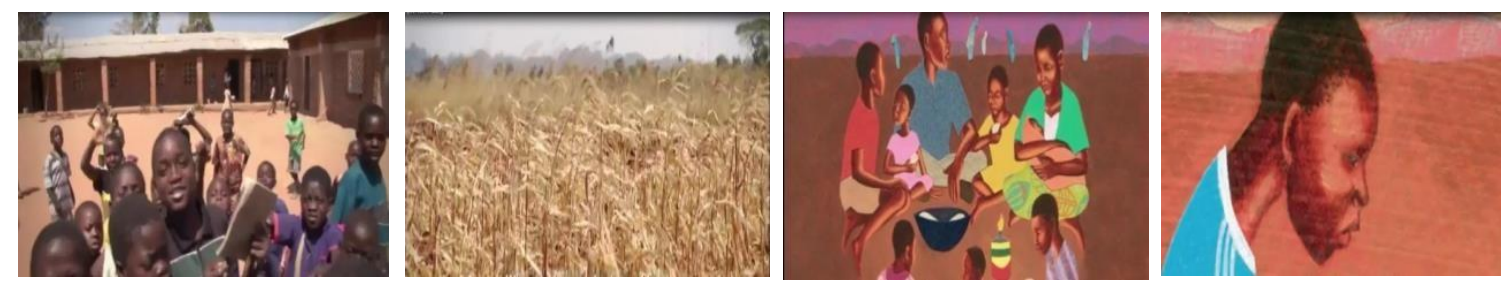

This article is licensed under CC BY-SA 4.0 License 

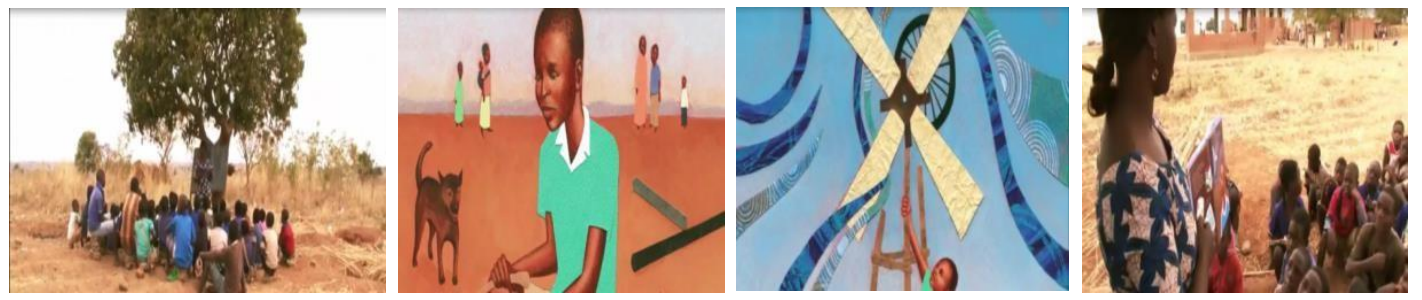

Figure 1. Some screenshots of the presented video,

Harnessing the Power of Reading (WeGiveBooks, n.d.)

The video illustrates a story about a poor boy, William Kamkwamba. William is a boy, who comes from Malawi, Africa. At the age of fourteen, he cannot continue his study anymore because of his family economic condition. This deteriorated economic condition is caused severe draught, which causes serious food shortage. The people suffer from severe hunger. There is no work at field anymore. William parents do not have any money to pay William's school fees, since they use the money for buying food. This condition forces William to drop out from his school. This situation influences William since he becomes hopeless. However, William starts waking up by learning at and borrowing books from a library run by an NGO. William starts learning the borrowed books. William is especially interested in sciences book, book on how to build a windmill. He is interested in building a windmill for generating electricity which enables pump extracted water for his village. Even though some people mock him, he perseveres. He keeps on trying and does not give up. He finally can build a windmill for his community. Now, William continues his study at Dartmouth College. His success inspires many young children at his village, Wembe. They want to be like William. To inspire other young children, William write a book, "The Boy who Harnessed the Wind." He is continually stimulating motivation to other people by doing book campaign and donating his books.

\section{Results}

The data analysis reveals that the student-participants can identify several values and characters which promote their self learning sustainability and community development. Some of them are able to connect learnt values with their self/real experiences. The following table presents the emergent themes, categories and data dispersion.

Table 1. The Emerging Themes

\begin{tabular}{l}
\hline Self-development: \\
\hline learning from reading (S1; S6; S8; S18; S25; S26; S27; S32;S42)/T1-1, perseverance (S2; S3; \\
S4;S15; S19:S21; S23; S24; S30; S35; S42)/T1-2, hard work (S4;S6; S12; 14)/T1-3, diligence \\
(S16)/T1-4, adopting new habit, change life (S22; S28, S33)/T1-5, self-confidence (S31)/T1-6 \\
\hline Community development: \\
\hline contributing knowledge to society (S4; S14; S17)/T2-1, making changes in community (S5; S18)/T2- \\
2, being useful to others /contributing to surrounding (S5; S9; S11: S12; S20)/T2-3, community \\
education empowerment, for instance educating children/young generation (S10; S34)/T2-4, \\
contributing what is read/learn to environment issues/detecting and trying to help solve the issue \\
(S13; S20; S37)/T2-5, doing real action for society (S29)/T2-6 \\
\hline S=Student-Participant
\end{tabular}

Each theme is discussed at the following section. Each category is represented by the excerpt of the sampled data. 


\section{Self Development}

The data reveal that the student-participants are able to extract lessons from the video and learn from the extracted values. Table 2 represents some data sample.

\section{Table 2. Self-Development}

\begin{tabular}{|c|c|}
\hline Students' Statement & Code \\
\hline $\begin{array}{l}\text { "So that we can learn that from reading we can chase our dream, many lesson we } \\
\text { can take from book, book can make us motivated to do something meaningful. } \\
\text { Then, lets start chase our dream from something simple, and it is reading." (S1) }\end{array}$ & T1-1 \\
\hline $\begin{array}{l}\text { "The lesson is nothing impossible if we are struggling and don't care who you are, } \\
\text { where you come from, if you not give up you can..." (S15) }\end{array}$ & $\mathrm{T} 1-2$ \\
\hline $\begin{array}{l}\text { "Moral value in this video is failure can't stop us, we just try to study hard and } \\
\text { work hard. We will useful for other people." (S12) }\end{array}$ & $\mathrm{T} 1-3$ \\
\hline $\begin{array}{l}\text { "If we study and read everywhere, every time, we can make our dream come true." } \\
\text { (S6) }\end{array}$ & $\mathrm{T} 1-4$ \\
\hline $\begin{array}{l}\text { "This story was so inspiring me. I am a lazy boy, I dislike to read book and when I } \\
\text { see him, I realized that have been better than him. I can go to library, but I don't. } \\
\text { Now, I have to start to go to library and start encourage myself to read books." } \\
\text { (S22) }\end{array}$ & $\mathrm{T} 1-5$ \\
\hline $\begin{array}{l}\text { "...So, don't ever think you are nothing. Try to think you are a thing. The you can } \\
\text { be super thing. Heroes can be in any place, in any time and any one. You can be } \\
\text { that heroes." (S31) }\end{array}$ & T1-6 \\
\hline
\end{tabular}

The data reveal that the student-participants are able to learn from the played video. The studentparticipants learn that it is vital to develop self, especially sustain their learning. Various ways, values and characters are identified and considered by the student-participants as important for self development, including developing self by being resourceful readers (S1/T1-1). Other students address several psychological states and characters to develop, such as perseverance (S1-5/T1-2), hard work (S12-T1-3), diligence (S6/T1-4) and self-confident (S31/T1-6). It is also found that self-development requires one' changing from less effective life style into healthier habit (such as stated by $S 22 / T 1-5$ ).

From the data, the study finds that to develop, they need to adopt several characters, such as being confident and diligent, persevering, working hard, learning continuously, and being self-conscious. This finding is inherent and confirming findings of existing studies which acknowledge interrelationship between self development and some psychological states, such as motivation, selfconsciousness and self-control. An autonomous self development is dependent on self determination or self capacity to guide his/her own behavior. Self determination addresses the roles of growth inclination and inner psychological needs as the ground of self-motivation, personality and their combination to reach positive process (Ryan \& Deci, 2000). Self-determination allows an individual to select and perform desired behavior and outcome (London \& Smither, 1999), grows motivation which is the basis of life goals/aspiration, source of energy and vitality, direction, perseverance, and equifinality (Deci \& Ryan, 2008).

Learning awareness shown by $S 1 / T 1-1$ is one way to develop self. Self development is a vital selfgoal influencing life and career development. One way to develop self is through adding knowledge and skills, or being resourceful, which can be undertaken by learning from people around you, library, technology (Iwata et al., 2017). This learning can occur everywhere (as stated by S6/T1-4), which indicates that learning can occur formally and informally. Self can be the encourager of his/her own self-learning through self-directed learning process. Self-directed learning capacity can promote self development through self-learning which can enhance human resource development in organization and social context (Ellinger, 2004). Self-directed learning is needed to reach some main self goals: self-learning motivation, transforming self and self-contribution to collective acts (Ellinger, 2004). Many studies show relationship between continuous learning and self-development (which validate $S 15 / T 1-3, S 12 / T 1-4, S 6 / T 1-5$ statements). Self-development is related to lifelong learning since 
developing self can progress during the entire the whole life and learning can occur informally (Sugiyama et al., 2014). Self-development and continuous education are essential construct today since it allows individual to be responsible of their own learning (London \& Smither, 1999).

The data also imply that learning in self-development tends to be autonomous, self-initiative and selfconsciousness based (S22/T1-5). This confirms the impact of self-learning monitor to self development. Self development capacity encourages people to learn from feedback, develop goals, undertake development acts and monitor self-progress (London \& Smither, 1999). Self-initiative based learning is the basis of self-growth. Self development is comprising of several components: learning design, self-diagnosis, goal setting, resource exploration, people recruitment, attempt, self-evaluation and lifelong learning structured process (Sugiyama et al., 2014).

Sustained self development is supported by committed learning (S12/ T1-3, S6/T1-4). Sustained self growth needs lifelong learning to develop selves through formal and informal learning (Jain et al., 2015). Self growth is a passion to develop every day (Jain et al., 2015). Some practices of self development: listens, considers other people's ideas, appreciates others, honesty and integrity, inspires and motivates others, welcome effective comments, takes initiatives and face risks (Practices SelfDevelopment. The Extraordinary Leader, 2015).

The data also reveal a student-participant self-awareness of his/her unhealthy habit, lazy character (S22/T1-5). He/she is motivated to change this ineffective habit and character. This indicates to be selfdeveloped, an individual needs to be aware of his/her own self: character, emotion and unhealthy life styles. Self-awareness guides individual to select desired values and characters and motivate himself/herself to behave consistently to the selected values and characters (Ugur et al., 2015). Autonomous self development depends on one's mindfulness (Deci \& Ryan, 2008) and self-capacity to undertake self-observation and self-inquiry (Lestari, 2015).

The data convey that self-efficacy significantly influences self development. To develop, an individual needs to be confident. This is as indicated by S31/T1-6 and S15/T1-2. Self efficacy is defined as an individual's perceived capacity to learn and execute tasks at desired levels (Bandura, 1997, cited in Schrunk \& Meece, 2005). Self efficacy affects self development (Schrunk \& Meece, 2005) since perceived self-efficacy influences four important processes in self: cognition, motivation, affection and selection (Bandura, 1993). Perceived self efficacy is affecting action moderated by affective, motivation and cognition (Bandura et al., 2001).

The data demonstrate that student-participants are aware that to develop themselves, they should energize themselves with positive emotion and control their negative affection (as revealed by $S 22 / T 1$ 5). $S 22$ changes his/her lazy tendency into more active learning. This indicates that he/she should able to control negative emotion. Self development is determined by one's capacity to be conscious of their emotion (Lewis et al., 1989). This emotion management can influence one's cognition, social and psychological mechanism (Gestsdottir \& Lerner, 2008), as self-cognitive functioning is controlled by self-regulatory, motivation and affection (Bandura, 1993).

\section{Self Contribution to Community Development}

The data indicate the relationship between self development and community development. The following table (Table 3) represents how the student-participants relate their development effort to community development.

Table 3. Self-contribution

\begin{tabular}{|c|c|}
\hline Students' Statement & Code \\
\hline $\begin{array}{l}\text { "We have to try again and again and also work hard to get our own desire. Learning } \\
\text { and contributing our knowledge to other..." (S4) }\end{array}$ & $\mathrm{T} 2-1$ \\
\hline $\begin{array}{l}\text { "...even we cannot study at school, it doesn't mean that we are stopping } \\
\text { learning... don't worry to make invention without any research. You can make } \\
\text { something useful for your family, your neighbor or maybe for your country..."(S18) }\end{array}$ & $\mathrm{T} 2-2$ \\
\hline
\end{tabular}




is, we have to find a way to make thing better. We can improve ourselves and try to
change things. Gain more knowledge and try to solve the problems in your
environment and society." (S20)
"...in my opinion, we must help them with the socialization about study is very
important and we can give some books for them, build the community that handles
the children problem."(S34)
"...but it's not enough with just keep reading and remember the information. T2-5
Understand, connect it with the issues in your environment, then you'll find a
treasure that could be so useful for others and world." (S13)
"Many people are bragging about their achievement and specialization, and they also T2-6
bragging about changing the world, but they contribute nothing to the society.
William is a great example for us to do something that really matter to the world, not
only spoken lies, but the real action and contribution. We should follow his example
to make our world and society to be a better place." (S29)
Theme

The data show that the student-participants reveal some inspiring lessons from the video, as inspired by William. This is inherent with the concept that video is an inspiring and engaging tool (Willmot et al., 2012). Some data also reveal that several student-participants connect their video-based lesson to their real experiences. This is as shown by the following table.

\section{Table 4. Video-Self experience connection}

\begin{tabular}{ll}
\hline \multicolumn{1}{c}{ Students' Statement } & Code \\
\hline "I have some experience that almost same with the first video. When I was in high & T2-Ex.1 \\
school, I joined group that focus in academic for street children. One day when I & \\
teach some boys, there is a boy that can make his own bag because he is reading a & \\
book and make it himself. After that many boys following his step to read a lot "how & \\
to" .." (S10) & \\
\hline "In my experience, I have ever see many children who can't study because their & T2-Ex.2 \\
parent don't have much money. They only lives at hub, and they work as cadger. It is & \\
very bad, because the young generation can't live comfortable. So, in my opinion, we & \\
must help them with the socialization about study is very important and we can give & \\
some books for them, build the community that handles the children problem."(S34) & \\
\hline T=Theme; Ex=Experience &
\end{tabular}

The data (as presented in Table 3 and Table 4) show that the student-participants are aware that they need to improve themselves for not only being useful for their own selves, but also for contributing to their community. The majority of the data show that the student-participants agree that by learning/through education, they can improve their knowledge and contribute their knowledge for community development (S4/T2-1; S18/T2-2; S20/T2-3; S34/T2-4; S13/T2-5). The student-participants are aware that their knowledge will be meaningful if they implement it to solve community issues (S18/T2-2; S20/T2-3; S34/T2-4; S13/T2-5; S29/T2-6).

The data indicate that the student-participants are aware that their self improvement relates to community development. To develop themselves, communities need contribution and engagement of their members, as development human capital and social capital. This finding relate to concept human and people participation in development as the key resources and investments for development sustainability.

The student-participants are ready to participate in development though learning. This demonstrates that the study validates and confirms the human development contribution aspect in community development. The success of empowerment is depending on participation (Behzad \& Ahmad, 2012; Fonchingong \& Fonjong, 2003; Nikkhah \& Redzuan, 2009)

The development progresses by involving all elements of community members. Community development values social inclusion to combat poverty and community problems (SCDC, n.d.). Community development is essentially a change action to empower community to be self-reliant and 
dependent through education (Behzad \& Ahmad, 2012). Thus, local community involvement is a necessity. Community involvement or social inclusion means people participation in development, which can be promoted through support provision for individual development, community building through democratic activity and social, economic chances (SCDC, n.d.). Participation insufficiency impedes community development, includes inconsistent activity, coordination, consciousness, knowledge, initiative, capital and integrity (Suridechakul, n.d.).

It can be indicated from the data that to be able to contribute to community development, the studentparticipants need to empower themselves through education. This means there is an interface between community participation and empowerment. Community development needs empowerment and participation besides collaboration, collective action led by community, citizenship, preventative measures, problem based learning (SCDC, n.d.). Thus, participation and empowerment are two interrelated construct in community development (Nikkhah \& Redzuan, 2009), which is confirmed by Midgley, et al (1986, cited in Fonchingong \& Fonjong, 2003, p. 204).

The study finds that the student-participants are highly motivated to develop community. This is as exemplified by S29/T2-6's statement “...We should follow his example to make our world and society to be a better place." The word, our, implies that $S 29$ has sense of community belongingness. This sense is vital ingredient for supporting development as development participation is moderated by psychological sense of community (Chavis \& Wandersman, 1990; Permut, 2016) and social identity (Howarth, 2001). Community tends to contribute to development on the basis of membership, collective emotion, mutuality, integration and contentment (McMilan \& Chavis, 1986, cited in Permut, 2016). The word our also implies togetherness and social cohesion in development. Togetherness and social cohesion are advocated as development resources and sustainability investment (Townsend, n.d.). Community development needs to solidify community and develop self-agency for empowering self-help, participative and need-felt community (Bhattacharyya, 2004). Social capital, as defined as how individuals and groups relate and cooperate, is regarded as resources for development (Kilpatrick et al., 2003). Social capital is substantive resource for self-empowered or self-help community development. Self-reliant community is independent community who can initiate, mobilize and utilize their own resources to support their own development (Fonchingong \& Fonjong, 2003), satisfy their own needs, engage themselves in collective mobilization and contribution (Chijioke, 2018). The selfreliant community fulfills their own basic needs (Fonchingong \& Fonjong, 2003).

The data reveal that the student-participants address the importance of education. Education is one of many approaches to build self and community capacity. Education empowers community to be selfreliant and independent (Behzad \& Ahmad, 2012). People self reliance capacity is vital for enabling them to develop themselves by using local resources and initiatives (Fonchingong \& Fonjong, 2003). Self help community develop through identifying basic need, practical education, value-based development, passion to change, sustainability through self-cohesion and solidarity (Chijioke, 2018). Social capital contributes to community self-help development. Social capital contributes to development through the development of institution, attitudes, norms (Tirmizi, 2005), social trust, collective measures and networks (the Asian Productivity Organization, 2006), collective associations and collective consciousness (Fedor, 2019), networks, social ties and working together (Adamtey \& Frimpong, 2018), networks and social functioning (Australian Bureau of Statistics, 2002), membership in community organization, social works and philanthropy (Jordan et al., 2010), social sharing and relationship (Kim, 2006).

The data indicate that the student-participants show motivation and self-efficacy to learn or gaining more knowledge which is meaningful for themselves and their communities. These emotional states are contributing factors of development. Self efficacy and confidence can be the catalyst of development (Cross \& Choudhury, 2005)

The data, which are presented in Table 4, show that the student-participants can connect lessons from video to their real experiences. The data also indicate that they are contributing to community through educational empowerment action (S10/T2-Ex.1) and public encouragement (S34/T2-Ex.2). This 
indicates relationship between human resources and development. Human resource is the key of community development (Bollman, 1999; Kwon, 2009; Razzaq et al., 2013; Son, 2010) and development in the future/sustainability (Šlaus \& Jacobs, 2011). This is because human is needed to manage other development resources (Eseyin et al., 2014), productive workforce for economic development (Son, 2010), creator who increases knowledge and connector who links self and environment (Kwon, 2009). Human knowledge, skill and consciousness are human elements' factors which determine the success of development (Razzaq et al., 2013). Development sustainability can be ensured through increasing human's consciousness (Šlaus \& Jacobs, 2011).

The data indicate that there is strong links between student-participants' learning and community improvement. Human capital contributes to development through changes in human capabilities enabling him/her to do things in new ways (Coleman, 1988, cited in Kwon, 2009). Education is advocated as one way to improve human capital to support development, as the main barrier development is human's lack of knowledge (Razzaq et al., 2013). Thus, human capital strongly relates to an individual knowledge, relationship, capacity for their employment (Galunic, 2000, cited in Kwon, 2009, p. 2) and education is regarded as the lever for human capital improvement in development (Šlaus \& Jacobs, 2011) since through human knowledge, skill, experience development can be achieved (Kwon, 2009; Ukwuaba, 2015). Because education is the lever, schooling and nonformal learning are some ways to enhance human capital quality. The improvement of human capital in schools (Ballif-Spanv et al., 2005) and higher education (Eseyin et al., 2014) are investment for education. Non formal education is a means of improving human capital, especially for aging and disadvantaged community members (Ukwuaba, 2015) and providing remedial, complementary, supplementary education (Ukwuaba, 2015).

\section{Model of Affective Function of Video, Self And Community Development}

The study reveals that video is catalyzing self-development awareness of the student-participants. It promotes the generation of psychological and mental states of self-motivation, perseverance, hard work, diligence, self efficacy and emotion regulation. The study also indicates that the studentparticipants show intentions to contribute to community development through education. This demonstrates relationship between self and community development. Educated, knowledged and skilled individual together with other members can progress community improvement through community participation/contribution. Thus, both human and social capitals are important resources for development as a quality/educated individual can be meaningful community members (Kwon, 2009; Part, 2003). Self has three faces: individual, relational and collective self (Sedikides et al., 2011). Self-learning or education is a way to improve quality of human and social resources enabling them to support and sustain community development. The following model represents the findings of the study.

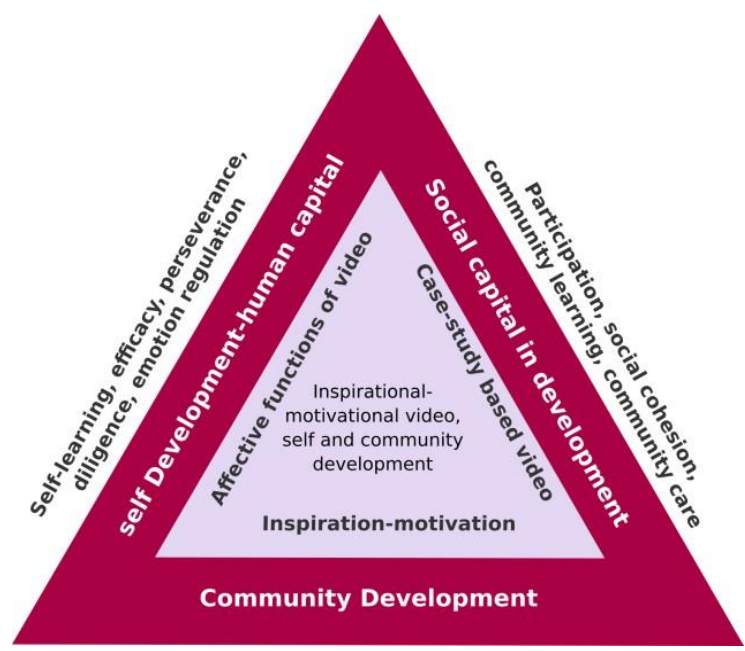

Figure 2. Model of inspirational-motivational video, self and community development 


\section{Conclusion}

This study aims to explore video affective function and student-participants learning. From the analysis, it is concluded that video facilitates students' awareness on the importance of selfdevelopment and community development. The study finds that several mental and psychological states allow the self-development process, including autonomous learning, self-perseverance, diligence, hard work, emotion regulation and self-efficacy. This self-development contributes to community development by preparing and developing human capital for development. Self-relied community development can be encouraged by social cohesion and community members' learning capacity. Thus, video is not only inspiring and motivating student-participants to improve themselves, but also moderating the community development through human and social capital growth.

\section{References}

Adamtey, R., \& Frimpong, J. (2018). Social capital as the missing link in community development planning process in Africa: Lessons from Ghana. Ghana Journal of Development Studies, 15(1), 92-115. https://doi.org/DOI//http://dx.doi.org/10.4314/gjds.v15i1.5

Australian Bureau of Statistics. (2002). Social capital and social well being (pp. 1-21) [Discussion Paper]. Commonwealth of Australia.

Badam, A. K., \& Pavani. (2018). The impact of positive role models on student's intent to choose respective medical special ties. Medical Science, 7(12).

Ballif-Spanv, B., Ward, C., Fuhriman, A., Solomon, Y., \& Widdison-Jones, K. (2005). Human capital and community development: A case study of an NGO-sponsored schooling program in Mali. World Studies in Education, 6(2), 29-52.

Bandura, A. (1993). Perceived self-efficacy in cognitive development and functioning. Educational Psychoogists, 28(2), 117-148.

Bandura, A., Caprara, G. V., Barbaranelli, C., Pastorelli, C., \& Regalia, C. (2001). Sociocognitive selfregulatory mechanisms governing transgressive behavior. Journal of Personality and Social Psychology, 1(80), 125-135. https://doi.org/DOI:10.1037//O022-3514.80.1.125

Behzad, S., \& Ahmad, N. (2012). The role of the community in community's development: Promotion of self dependence through education. African Journal of Business Management, 6(49), 11896-11901. https://doi.org/DOI: 10.5897/AJBM10.1603

Berger, B. K., Meng, J., \& Heyman, W. (2009). Role modeling in public relations: the influence of role models and mentors on leadership beliefs and qualities. Research That Matters to the Practice, 10-17.

Bhattacharyya, J. (2004). Theorizing community development. Journal of the Community Development Society, 34(2), 5-137.

Blaylock, M., Churches, R., Gowers, F., Mackenzie, N., McCauley, D., \& Pye, M. (n.d.). Inspiring teachers: How teachers inspire learners (pp. 1-48). Education Development Trust.

Bollman, R. D. (1999). Human capital and rural development: What are the linkages? (Working Paper No. 39). Statistics Canada Agriculture Division.

Bosma, N., Hessels, J., Schutjens, V., van Praag, M., \& Verheul, I. (2011). Entrepreneurship and role models (Discussion Paper TI 2011-061/3; Tinbergen Institute Discussion Paper, pp. 1-28). Tinbergen Institute Amsterdam. http://www.tinbergen.nl

Brame, C. (n.d.). Effective educational videos. Vanderbilt University.

Bravo, E., Amante, B., Simo, P., Enache, M., \& Fernandez, V. (2011). Video as a new teaching tool to increase student motivation. Conference Paper. https://doi.org/DOI: 10.1109/EDUCON.2011.5773205

Brecht, H. D. (2012). Learning from online video lectures. Journal of Information Technology Education: Innovations in Practice, 11, 227-250. 
Buzzetto-More, N. A. (2014). An examination of undergraduate student's perceptions and predilections of the use of youtube in the teaching and learning process. Interdisciplinary Journal of E-Learning and Learning Objects, 10, 17-23.

Bzonková, Z. (2018). Video as a motivational factor in teaching and learning english [Diploma Thesis]. Masaryk University.

Carmichael, M., Reid, A.-K., \& Karpicke, J. D. (n.d.). Assessing the impact of educational video on student engagement, critical thinking and learning: The current state of play. Sage Publishing. www.sagepublishing.com

Chao, T., Chen, J., Star, J. R., \& Dede, C. (2016). Using digital resources for motivation and engagement in learning mathematics: Reflections from teachers and students. Digit Exp Math Educ, 2, 253-277. https://doi.org/DOI 10.1007/s40751-016-0024-6

Chavis, D. M., \& Wandersman, A. (1990). Sense of community in the urban environment: A catalyst for participation and community development. American Journal of Community Psychology, 18(1).

Chijioke, O. C. (2018). The effect of self-help as a productive strategy for sustainable community development in Nigeria. International Journal of Business and Management Invention, 7(5), 32-39.

Chlosta, S., Patzelt, H., Klein, S. B., \& Dormann, C. (2012). Parental role models and the decision to become self-employed: The moderating effect of personality. Small Bus Econ, 38, 121-138. https://doi.org/DOI 10.1007/s11187-010-9270-y

Choe, E. (2017). Optimizing video for learning: A case study-based primer of informal, educational, digital video best practices. Massachusetts Institute of Technology, Cambridge, MA, USA. https://ssrn.com/abstract=2909769

Chung, E. J., \& Lee, B.-H. (2018). The effects of flipped learning on learning motivation and attitudes in a class of college physical therapy students. Journal of Problem-Based Learning, 5(1), 2936.

Creswell, J. W. (2007). Qualitative inquiry \& research design. Choosing among five approaches (2nd Ed.). Sage Publications, Inc.

Cross, H., \& Choudhury, R. (2005). Self care: A catalyst for community development. Asia Pacific Disability Rehabilitation Journal, 16(2), 100-114.

Daskalovska, N., Gudeva, L. K., \& Ivanovska, B. (2012). Learner motivation and interest. Procedia Social and Behavioral Sciences, 46, 1187 - 1191. https://doi.org/doi: 10.1016/j.sbspro.2012.05.272

Deci, E. L., \& Ryan, R. M. (2008). Self-determination theory: A macrotheory of human motivation, development, and health. Canadian Psychology, 49(3), 182-185. https://doi.org/DOI: $10.1037 / \mathrm{a} 0012801$

Derounian, J. G. (2017). Inspirational teaching in higher education: What does it look, sound and feel like? International Journal for the Scholarship of Teaching and Learning, 11(1), 1-5. https://doi.org/10.20429/ijsotl.2017.110109

Douad, B. (n.d.). Motivation and learning modes: Towards an automatic intelligent evaluation of learner motivation (V.3-N.1). DIGITAL UNIVERSITIES International Best Practices and Applications.

Ellinger, A. D. (2004). The concept of self-directed learning and its implications for human resource development. Advances in Developing Human Resources, 6(2), 158-177. https://doi.org/DOI: $10.1177 / 1523422304263327$

Eseyin, E. O., Uchendu, E. E., \& Bright, I. B. (2014). Higher Nigeria. International Journal of Education and Research, 2(6), 591-600.

Fedor, C.-G. (2019). Social capital and community development: A case study. Social Research Reports, 11(1), 65-77. https://doi.org/10.33788/srr11.1.5

Fonchingong, C. C., \& Fonjong, L. N. (2003). The concept of self-reliance in community development initiatives in the Cameroon Grassfields. Nordic Journal of African Studies, 12(2), 196-219. 
Francis, J. (2017). The effects of technology on student motivation and engagement in classroombased learning [Dissertation]. University of New England.

Gestsdottir, S., \& Lerner, R. M. (2008). Positive Development in adolescence: The development and role of intentional self-regulation. Human Development, 51, 202-224. https://doi.org/DOI: $10.1159 / 000135757$

Gilakjani, A. P. (2012). The significant role of multimedia in motivating efl learners' interest in english language learning. I.J.Modern Education and Computer Science, 4, 75-66. https://doi.org/DOI: 10.5815/ijmecs.2012.04.08

Handley, R. (2008). Using technology to motivate student learning. Proceedings of the Emerging Technologies Conference. http://ro.uow.edu.au/etc08/10

Haque, M. (2017). Influence of role model for professional development in medical education. Journal of Global Pharma Technology, 12(9), 10-18.

Hoskins, S. L., \& Newstead, S. E. (2003). Encouraging student motivation. In A Handbook for Teaching and Learning in Higher Education (3rd, edited by H. Fry, S. Ketteridge \& S. Marshall ed., pp. 27-39). Routledge.

Howarth, C. (2001). Towards a social psychology of community: A social representations perspective. Journal for the Theory of Social Behaviour, 31(2), 223-238. https://doi.org/DOI: 10.1111/1468-5914.00155

Hurd, N. M., Wittrup, A., \& Zimmerman, M. A. (2011). Role models in adolescent development.

Iwata, D., Jones, H., Young-Havens, A., \& Martin, K. (2017). Being resourceful in your selfdevelopment. Resource Information for Classified Employees.

Jain, C. R., Apple, D. K., \& Ellis, W. (2015). What is self-growth? International Journal of Process Education, 7(1), 41-52.

Jensen, K., Adams, J., \& Strickland, K. (2014). Inspirational teaching: Beyond excellence and towards collaboration for learning with sustained impact. Journal of Perspectives in Applied Academic Practice, 2(2), 37-41.

Jordan, J. L., Anil, B., \& Munasib, A. (2010). Community Development and local social capital. Journal of Agricultural and Applied Economics, 42(1), 143-159.

Joubert, P., Krüger, C., Bergh, A.-M., Pickworth, G., Van Staden, C., Roos, J., Schurink, W., Du Preez, R., Grey, S., \& Lindeque, B. (2006). Medical students on the value of role models for developing 'soft skills'-“That's the way you do it." S Afr Psychiatry Rev, 9, 28-32.

Kilpatrick, S., Field, J., \& Falk, I. (2003). Social capital: An analytical tool for exploring lifelong learning and community development. British Educational Research Journal, 29(3), 417-433. https://doi.org/DOI: 10.1080/0141192031000156024

Kim, H. Y. (2006). Assessing the role of social capital in th ecommunity development field: A multilevel analysis [Dissertation]. The University of Georgia.

Kokić, I. B., \& Rukavina, S. (2017). Learning from digital video cases: How future teachers perceive the use of open source tools and open educational resources. Knowledge Cultures, 5(5), 115130. https://doi.org/doi:10.22381/KC5520177

Kuchel, L. J., Stevens, S. K., Wilson, R., \& Cokley, J. (2014). A Documentary video assignment to enhance learning in large first-year science classes. International Journal of Innovation in Science and Mathematics Education, 22(4), 48-64.

Kwon, D.-B. (2009). Human capital and its measurement. Statistics, Knowledge and Policy" Charting Progress, Building Visions, Improving Life, 1-15. http://www.oecdworldforum2009.org

Lestari, S. E. (2015). Self-development through self-observation for teacher of English as a foreign language. Wahana Inovasi, 4(2), 652-658.

Lewis, M., Sullivan, M. W., Stanger, C., \& Weiss, M. (1989). Self development and self-conscious emotions. Child Development, 60(1), 146-156.

Liu, E. Z.-F., Lin, C.-H., Jian, P.-H., \& Liou, P.-Y. (2012). The dynamics of motivation and learning strategy in a creativity-supporting learning environment in higher education. TOJET: The Turkish Online Journal of Educational Technology, 11(1), 172-180. 
Ljubojevic, M., Vaskovic, V., Stankovic, S., \& Vaskovic, J. (2014). Using Supplementary video in multimedia instruction as a teaching tool to increase efficiency of learning and quality of experience. The International Review of Research in Open and Distance Learning, 15(3), 273291.

Lockwood, P., Jordan, C. H., \& Kunda, Z. (2002). Motivation by positive or negative role models: Regulatory focus determines who will best inspire us. Journal of Personality and Social Psychology, 83(4), 854 - 864. https://doi.org/DOI: 10.1037//0022-3514.83.4.854

London, M., \& Smither, J. W. (1999). Empowered self-development and continuous learning. Human Resource Management, 38(1), 3-15.

Lund, S. (2016). Making learning authentic: An educational case study describing student engagement and motivation in a project-based learning environment [Dissertation]. Arizona State University.

Malouff, J. M., Rooke, S. E., Schutte, N. S., Foster, R. M., \& Bhullar, N. (2008). Methods of motivational teaching. University of New England.

Manning, C., Aliefendic, J., Chiarelli, M. A., Haas, L., \& Williams, S. (2011). Inspirational impetuous: lifelong learning. SRATE Journal, 21(1), 11-17.

Ma'rifah, U., \& Wulandari, R. E. (2013). Using interactive video to imporove students otivation in learning english. Didaktika, 17(2), 81-87.

Miller, L. M., Chang, C.-I., Wang, S., Beier, M. E., \& Klisch, Y. (2011). Learning and motivational impacts of a multimedia science game. Computers \& Education, 57, 1425-1433. https://doi.org/doi:10.1016/j.compedu.2011.01.016

Morgenroth, T., Ryan, M. K., \& Peters, K. (2015). The motivational theory of role modeling: How role models influence role aspirants' goals. review of general psychology. Advance Online Publication. http://dx.doi.org/10.1037/gpr0000059

Muofhe, N. J., \& du Toit, W. F. (2011). Entrepreneurial education's and entrepreneurial role models' influence on career choice. SA Journal of Human Resource Management, 9(1). http://dx.doi.org/10.4102/ sajhrm.v9i1.345

Murphy, E., \& Rodríguez-Manzanares, M. A. (n.d.). Teachers' perspectives on motivation in high school distance education. Journal of Distance Education, 23(3), 1-24.

Nikkhah, H. A., \& Redzuan, M. (2009). Participation as a medium of empowerment in community development. European Journal of Social Sciences, 11(1), 170-176.

Noraddin, E. (2015). Three learning potentials in digital games: Perception of Malaysian University teachers. The Online Journal of Distance Education and E-Learning, 3(3), 78-89.

Panagiotidis, P., Krystalli, P., \& Arvanitis, P. (2018). Technology as a motivational factor in foreign language learning. European Journal of Education, 1(3), 43-52.

Park, Y., \& Jung, E. (2016). Exploring the use of video-clips for motivation building in a secondary school efl setting. English Language Teaching, 9(10), 81-89.

Part, E. (2003). Interrelationships between human capital and social capital: Implications for economic development in transition economies (Grant Paper No. 5369; pp. 7-34). Tartu University Press.

Permut, M. (2016). Psychological sense of community as an example of prefiguration among occupy protesters. Journal of Social and Political Psychology, 4(1), 180-195. https://doi.org/doi:10.5964/jspp.v4i1.533

Piccinato, C. E., Rodrigues, M. de L. V., Rocha, L. de A., \& Troncon, L. E. de A. (2014). Characteristics of role models who influenced medical residents to choose surgery as a specialty: Exploratory study. The Association for Medical Education in Europe (AMEE) meeting, Italy.

Pintrich, P. R. (1999). The role of motivation in promoting and sustaining self-regulated learning. International Journal of Educational Research, 31, 459-470.

Pintrich, P. R. (2000). The role of goal orientation in self-regulated learning. In Handbook of SelfRegula6on. Academic Press. 
Pirhonen, J., \& Rasi, P. (2017). Student-generated instructional videos facilitate learning through positive emotions. Journal of Biological Education, 51(3), 215-227. https://doi.org/doi:10.1080/00219266.2016.1200647

Popenici, S. (n.d.). Role models, student engagement and social success. Mcquaire University. Practices self-development. The extraordinary leader (pp. 1-8). (2015). Zenger Folkman.

Rakhmanina, L., \& Kusumaningrum, D. (2017). The effectiveness of video blogging in teaching speaking viewed from students' learning motivation. Proceedings of the Fifth International Seminar on EnglishLanguage and Teaching, 27-34.

Razzaq, A. R. A., Mohamad, N. H., Kader, S. S. S. A., Mustafad, M. Z., Hadi, M. Y. Ab., Hamzah, A., \& Khalifah, Z. (2013). Developing Human Capital for Rural Community Tourism: Using Experiential Learning Approach. Procedia - Social and Behavioral Sciences, 93, 1835-1839. https://doi.org/doi: 10.1016/j.sbspro.2013.10.126

Rudhumbu, N. (2014). Motivational strategies in the teaching of primary school mathematics in Zimbabwe. International Journal of Education Learning and Development, 2(2), 76-103.

Ruttherford, C. (2012). Research design. In Researching Society and Culture (3rd Ed. C. Seale (Ed.), pp. 118-133). SAGE Publication Ltd.

Ryan, R. M., \& Deci, E. L. (2000). Self-determination theory and the facilitation of intrinsic motivation, social development, and well-being. American Psychologist, 55(1), 68-78. https://doi.org/DOI: 10.1037110003-066X.55.1.68

Sammons, P., Lindorff, A., Kington, A., \& Ortega, L. (2016). Inspiring teaching: Learning from exemplary practitioners. Journal of Professional Capital \& Community, 1-21.

SCDC. (n.d.). Community development values (Supporting Best Practice in Community Development). Scottish Community Development Centre.

Schrunk, D. H., \& Meece, J. L. (2005). Self-efficacy development in adolescences. Self-Efficacy Beliefs of Adolescents, 71-96.

Sedikides, C., Gaertner, L., \& O’Mara, E. M. (2011). Individual self, relational self, collective self: hierarchical ordering of the tripartite self. Psychol Stud, 56(1), 98-107. https://doi.org/DOI 10.1007/s12646-011-0059-0

Shaheen, S., Perveen, N., Noshaba, \& Malikz, S. K. (2013). Motivational techniques for effective learning: A meta analysis. Educational Technology, 64, 19170-19176.

Shephard, K. (2008). Higher education for sustainability: Seeking affective learning outcomes. International Journal of Sustainability in Higher Education, 9(1), 87-98. https://doi.org/DOI 10.1108/14676370810842201

Šlaus, I., \& Jacobs, G. (2011). Human capital and sustainability. Sustainability, 3, 97-154. https://doi.org/doi:10.3390/su3010097

Son, H. H. (2010). Human capital development (Working Series Paper No. 225; ADB Economics Working Paper Series, pp. 1-25). Asian Development Bank.

Stefanova, T. A. (2014). Using of training video films in the engineering education. Procedia-Social and Behavioural Sciences, 116, 1181-1186. https://doi.org/doi: 10.1016/j.sbspro.2014.01.366

Stern, M. J., Frensley, B. T., Powell, R. B., \& Ardoin, N. M. (2017). What difference do role models make? Investigating outcomes at a residential environmental education center. Environmental Education Research. http://dx.doi.org/10.1080/13504622.2017.1313391.

Sugiyama, L., Pathumcharoenwattana, W., \& Burasirirak, S. (2014). The main components of selfdevelopment model to enhance non-formal education facilitators' potential in lifelong education management. The Asian Conference on Education.

Suridechakul, W. (n.d.). Factors affecting sustainable community development: A case studyof dusit district community. Recent Advances on Energy, Environment, Ecosystems, and Development, $106-110$.

the Asian Productivity Organization. (2006). Potential of social capital for community development (pp. 3-249). The Asian Productivity Organization.

Tirmizi, S. N. A. (2005). The contribution of levels of social capital to community development [Dissertation, Iowa State University]. https://lib.dr.iastate.edu/rtd/1599 
Tjakrawadhana, V. R. K. (n.d.). German language learning through video to improve students' motivation and introduce German culture. 267-272.

Townsend, W. (n.d.). The importance of social capital. An analysis of volunteer placements. Aalborg University.

Ugur, H., Constantinescu, P.-M., \& Stevens, M. J. (2015). Self-awareness and personal growth: Theory and application of bloom's taxonomy. Eurasian Journal of Educational Research, 60, 89-110.

Ukwuaba, L. C. (2015). Maximizing human capital development (HCD) through non-formal education (NFE). International Journal of Education and Research, 3(8). www.ijern.com

Usón, S., Peña, B., Zabalza, I., Llera, E. M., \& Romeo, L. M. (2018). Combining flipped classroom model and educational videos for improving teaching-learning process in thermodynamics $\begin{array}{llll}\text { and thermal } & \text { (1329). }\end{array}$ https://doi.org/doi:10.3390/proceedings2211329

Valero, D., Keller, A. C., \& Hirschi, A. (2017). The perceived influence of role models and early career development in native and migrant youth. Journal of Career Development, 1-30.

WeGiveBooks. (n.d.). Harnessing the power of reading [Video]. https://m.youtube.com/watch?v=6AkKpYknjyA

Weissmann, P. F., Branch, W. T., Gracey, C. F., Haidet, P., \& Frankel, R. M. (2016). Role modeling humanistic behavior: learning bedside manner from the experts. Academic Medicine, 81(7), 661-667.

Wieking, B. A. (2016). Technology integration and student learning motivation. Northwestern College.

Williams, K. C., \& Williams, C. C. (n.d.). Five key ingredients for improving student motivation. Research in Higher Education Journal, 1-23.

Willmot, P., Bramhall, M., \& Radley, K. (2012). Using digital video reporting to inspire and engage students. National HE Stem Programme, The Royal Academy of Engineering, Engineering Subject Centre.

Woolfitt, Z. (2015). The effective use of video in higher education. Inholland University of Applied Sciences.

Yuen, M.-C., Koo, A.-C., \& Woods, P. C. (2018). Online video for self-directed learning in digital animation. TOJET: The Turkish Online Journal of Educational Technology, 17(3), 91-103. 